\title{
Architectural Style of Riverside Settlements in Banjarmasin City
}

\author{
Amar Rizqi Afdholy ${ }^{{ }^{*}}$, Lisa Dwi Wulandari ${ }^{2}$, Sri Utami ${ }^{3}$ \\ 1. Magister Architecture, University of Brawijaya, Malang, Indonesia \\ 2. Department Architecture, University of Brawijaya, Malang, Indonesia \\ Corresponding Author: amayrizqi30@gmail.com
}

\begin{abstract}
Keywords:

style

architecture, vernacular, house of river settlement, banjarmasin

Riverside settlements in Banjarmasin City can be classified as a part of vernacular architecture; the initial researchers made this classification. This classification underlying the research about architecture style in one of the riverside settlements in Banjarmasin City which still has strong riverside culture, the focus point of this research is at the riverside settlements of Bromo Island Delta, Mantuil, Banjar Selatan subdistrict, Banjarmasin City. The determination of these assessments refers to vernacular architecture style using a qualitative research method and purposive sampling technique. From 25 samples, we found 2 styles of architecture on the riverside settlements in Bromo Island Delta. They are vernacular architecture and semi vernacular architecture style. Addition of space function, the change of foundation structure and material, economy and community knowledge about recent technology are the development factors of vernacular houses changes into semi vernacular houses.
\end{abstract}

\section{Abstrak}

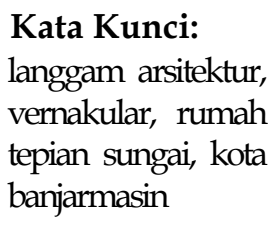

Langgam arsitektur pada permukiman tepian sungai Kota Banjarmasin pada awalnya dapat digolongkan pada langgam arsitektur vernakular, ini juga didasari oleh beberapa pendapat peneliti terdahulu yang meneyebutkan bahwa permukiman tepian sungai di Kota Banjarmasin terdiri dari rumah-rumah dengan langgam arsitektur vernakular. Hal ini pula yang mendasari penelitian untuk melihat jenis langgam arsitektur pada salah satu permukiman tepian sungai Kota Banjarmasin yang masih memiliki budaya sungai yang kuat, yaitu pada permukiman tepian sungai Delta Pulau Bromo, Kelurahan Mantuil, Kecamatan Banjarmasin Selatan, Kota Banjarmasin. Penentuan pada penilaian langgam ini mengacu pada langgam arsitektur vernakular, dengan metode penelitian kualitatif dan teknik penentuan sampel menggunakan purposive sampling. Dari 25 sampel yang terpilih didapati dua jenis langgam arsitektur pada rumah di permukiman tepian sungai Delta Pulau Bromo, yaitu rumah dengan langgam arsitektur vernakular dan rumah dengan langgam arsitektur semi vernakular. Penambahan fungsi ruang, perubahanan bentuk pondasi dan material, ekonomi serta faktor pengetahuan masyarakat tentang teknologi terbaru, menjadi dasar dari perkembangan rumah-rumah vernakular menjadi rumah semi vernakular. 


\section{Introduction}

Banjarmasin City is an archipelago city, consists of small islands and cities separated by rivers. In the macro context, Banjarmasin City is a region with physical geographic boundaries that has many rivers, $40 \%$ of the region consisted of either big or small rivers intersect each other. Banjarmasin city has its own area characteristic that can be seen from riverside settlements with its riverside architecture and the people culture of the river existence itself. The riverside settlements were built with the environment responses, which gives a unique character to the building's façade and form as an adaptation process.

In Architecture, building's form shows a style of a building or the style itself. The style also can be called for design taste or model. Style can be defined as a shape or form, rules and unique set from an era in a specific place (Rahayu, 2017). According to Iskandar (2004), the style definition refers to more specific things, involving unique characters or ornaments at certain times, certain period, a certain area or certain people. Jules (in Iskandar, 2004), also mentions that style depends on situations, conditions and contradictions happened in people's life. The power among people with styles can be transformed into a beauty, reflecting the existing culture. Architecture style generaly adapted from the environment's life with the use of local material (Sudarwani, 2012). An architecture style can be seen from the unique character of the building's form.

Riverside architecture in Banjarmasin City is a result of people adaptation process influenced by the river environment. Based on the statement of Mentayani \& Prayitno, (2011); Mentayani (2010); Mentayani, (2016) and Dahliani et al, (2016) that said riverside settlements in Banjarmasin City is a settlement consisted by vernacular houses existed since long time ago and grown based on its character and locality. From that point of view, the criteria of architecture vernacular can be used to see the style of riverside settlements in Banjarmasin City.

\section{Vernacular architecture aspect}

Vernacular words are originated from vernaculus, which means the original. Vernacular refers to the used language of time, place or some local community. In culture, especially architecture, vernacular refers to the type of culture or architecture's form applied to a specified place, not imitated from any other place. Vernacular in architecture pointing to the building that had some local elements. Vernacular architecture can be perceptible as a simple building style usually used to regular housings (Abioso, 2011). Vernacular architecture is an architectural form that was made from the people responses to the local climate passing by trial and error processes. Rapoport (1969), explains vernacular architecture actually doesn't have a clear identity of its original designer. From that points, vernacular culture can be understood as an original culture owned by some socially developed community considered with the surrounding environment.

Vernacular's aspects are the fundamental aspects of reviewing architectural work, which is vernacular architecture. According to Mentayani \& Ikaputra (2012), vernacular architecture has 2 (two) field and element, they are form and meaning. Form element stands in a physical field, while the meanings stand in an abstract field. Both form and meanings each have 3 (three) vernacularity aspects that are:

\section{a. Technical Aspect}

In the technical aspect, the things that become the vernacular factors, either in the form or meaning element are the things related to engineering, such as: how to build, the construction technique used, the material is chosen, and other technical things that have function value and contain meaning based on the local tradition. 
b. Cultural Aspect

In the context of vernacular architecture form's manifestation, they were endeavoured to appear as an expression of the local people, not just related to its physical buildings but also the spirit and soul contained inside it. This clarifying how much important houses are to human being and they still follow the valid rules and the followed patterns since ancient times. According to Mentayani \& Ikaputra (2012), the cultural aspect in the physical field is formed as symbols, meanwhile in the abstract field is formed as a conveyed message. Symbols in architecture related to denotation symbols which are a benefit or merit existed in some things that can be felt or seen.

c. Environmental Aspect

Vernacular architecture has the same form or style in a certain place but different from others by adjusting the tradition and condition of the people's social-culture. Rapoport (1969) mentions about the cultural landscape that all of the humanist growth tends to point out vernacularly. Rapoport also stated landscape has a special culture, where one location has a different character to the others. According to Mentayani \& Ikaputra (2012), vernacular architecture is a human dialogue to the environment, reactions to environment factors, the material limitations, culture and technology also in the social related context. In the environment aspect, vernacularity factors either on the form or meaning elements are the environment adapting into houses form and save its meanings (such as forest, river, mountain, etc.)

\section{Riverside Settlements Characteristic in Banjarmasin City}

The formations of Banjar's tribe had a strong influence on architecture development in South Kalimantan region. In the early days of the formations until the end of the $70^{\prime}$ s, there still many Banjar people live on boats nomadically. Around the ' 80 s, the floating house starts to shows up on the river's surface. Floating houses are the adaptation of the boat people population pressure. Besides it's built by the people who were lived on a boat, this floating house also carried from the outside area of Banjarmasin, precisely from the upstream area (Mentayani, 2016). Because at that time the trading activity was growing rapidly in the Banjarmasin's rivers area, then appealing the merchants outside the city to trading in Banjarmasin's rivers.

This floating house growth also followed by the growth of stilt houses along the riverside, the merchant's floating house that used to move around for saving times then choose to tether until it settles with a built of the riverside stilt house as a productions place for the commodity. The bond between floating house owners and the local people gives them easiness to stay and build a permanent house on the riverside for a living (Mentayani, 2016). The convenience of access on the life necessities from the river became the basic reasons of riverside houses establishments. The riverside houses' pattern generally is linear following the river's shape and the housing development point to the sideway, not backwards.

The riverside people's life implicated in the floating house, the riverbank house and the riverside house (Mentayani, 2016). The riverside settlements have a few types of buildings, this type can be seen from the aspect of a building's position and location that influenced by the used construction. 3 types of riverside house are mention as below, (Picture 2.6):

a. Rumah Tepi Sungai (Riverside houses) are the riverside house existed on the road sideways and facing to the river. This house using stilt house constructions and stands on the marshland. 
b. Rumah Bantaran Sungai (Riverbank houses), are the riverside house lied on the river's surfaces with stilt house constructions that influenced by the river's ebb and flow.

c. Rumah Lanting (Floating houses), is the riverside house lied above the river's surface with floating constructions, this house is floating and oriented to the river.

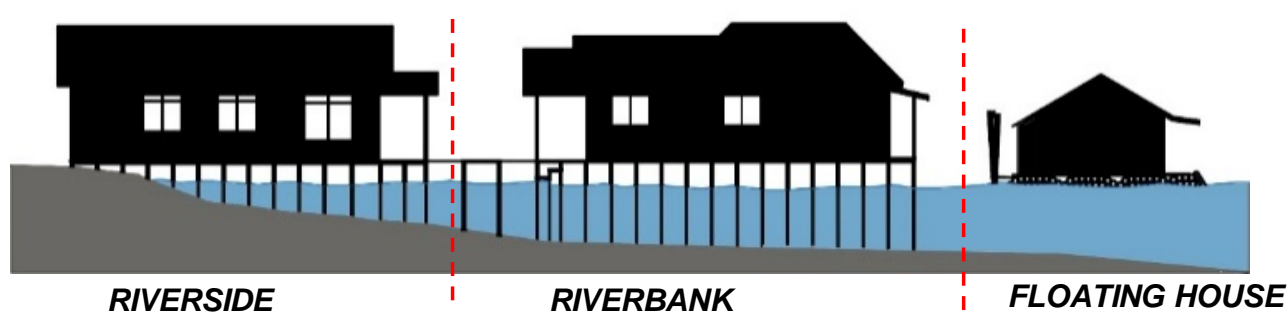

Figure 1. Riverside houses type

The river environments in Banjarmasin City also affecting the riverside people's social and culture activity. To support the riverside people daily activity, then the support elements emerge on the houses connecting people to the river such as Titian (footbridge), jamban (toilet), dermaga (the dock) and batang (plank of wood used as a bridge) that influence and support the people's life activity.

\section{Research's Location and Method}

The research located at one of the riverside settlements that still original which are riverside settlements of Bromo Island's Delta or in Indonesia called Delta Pulau Bromo (DPB), Kelurahan Mantuil, South Banjarmasin Sub-district, Banjarmasin City, South Kalimantan. The settlements have about $3 \mathrm{Km}$ distance from Banjarmasin's downtown. This Bromo Island has a form of a delta (a small island in the middle of the river) surrounded by Martapura River and Barito River.

DPB Settlements can only be reached by using water transportation such as a boat or ferry. The environment physically stands on river surroundings dominated by nature elements like marshland, garden and farmland. The circulations of DPB Settlements form as a linear pattern following the shape of Martapura River and Barito River which is stand around the settlements itself. The people's live here still really depend on the river, this is the reasons why the culture still strong, the people activity which affected by the river still can be seen original just as the people's life of old times in Banjarmasin City.

The research method used in this research is a qualitative descriptive method. The qualitative method by Creswell (2014) defined as a research method to understands human or social problems by creating an overall and complex depiction served with words. This method selected because we need to observe the phenomenon happened in the area, which is to discover the style of riverside settlements in Banjarmasin City with the objects are the houses located on the riverside. The technique used to choose the sample in this research is purposive sampling, a sample election technique which is seen based on the special characteristic that lies on riverside houses object, such as the house dominated by nature materials and the house that has support elements like titian (footbridge), batang (plank of wood used as bridge), dermaga (the dock) and jamban (toilet). This characteristic selected to see the vernacularity value of a house. The respondents are the selected DPB riverside houses residents, which help us to know the daily activity of people in riverside settlements.

The research area range only took on the existed houses in Maratapura River estuary that lies in DPB, which are RT 06 and RT 07. By considering the existence of floating houses 
on the riverside, which that area still have the variety of riverside houses and the river influenced culture for this case study.

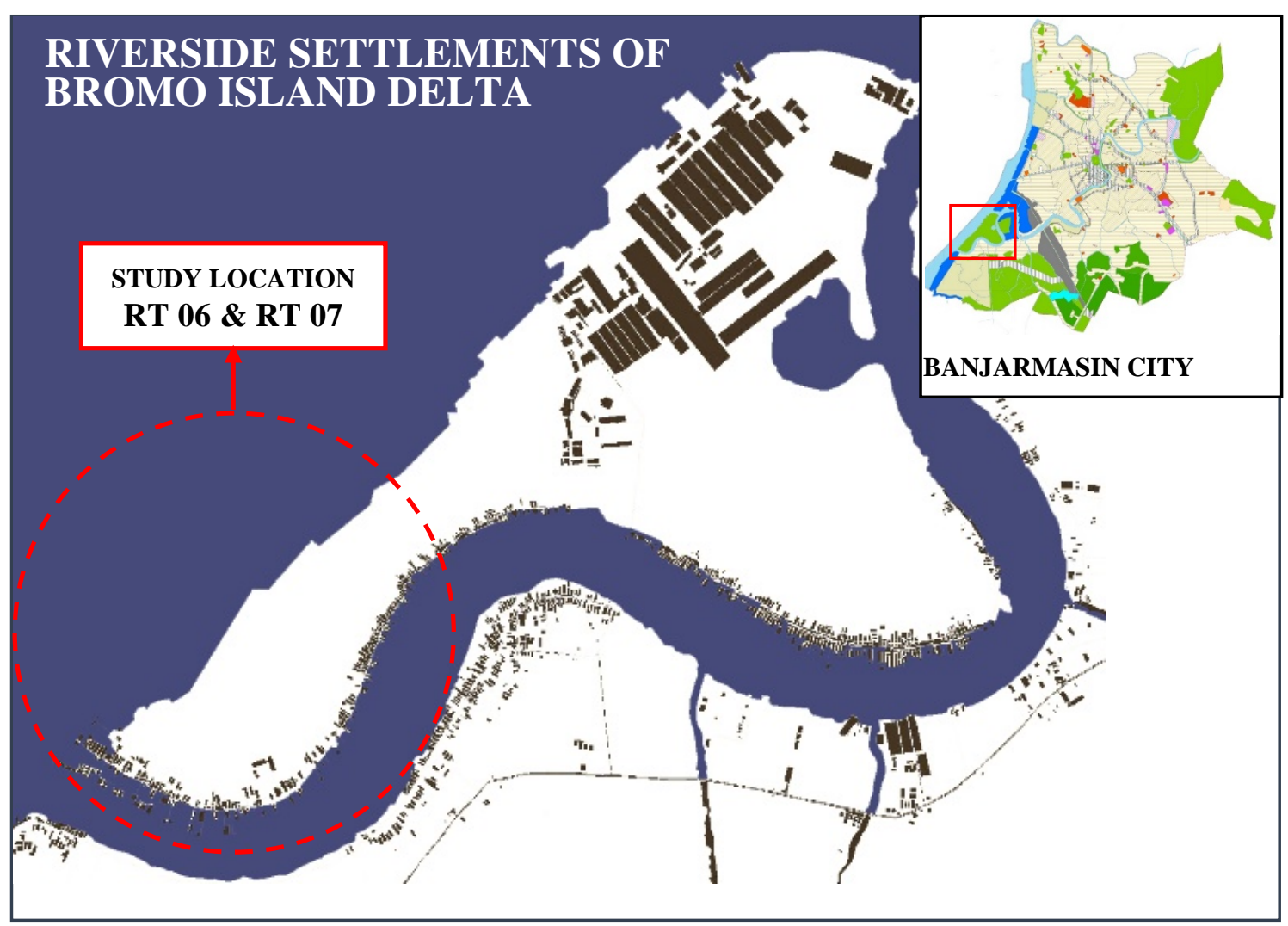

Figure 2. Research Map Location

\section{Result and Discussion}

The building style is a characteristic or a special identity form of a building. To find out what architecture style used in a building, we need to know what characteristic it is adapting to the appointed style's rule. On this DPB riverside settlements, the determination of the architecture style refers to the vernacular architecture style. This style determination based on the previous research that mentioned riverside settlements style in Banjarmasin City is Vernacular Architecture.

Vernacular architecture style determination of a house can be seen from a few aspects such as: (1). Technical Aspect that observes a house from its physical appearance. This physical character can be formed as a building shape, construction used and does the material still use the material from nature. (2) Cultural Aspect to observe how much the culture influence to the house, in the case of Riverside settlements it is observing from the culture influenced existence towards the residents and their house. (3) Environmental Aspect to observe the adaption of building form towards nature environment which is affected by the river. That 3 aspects are expected to become a reference to evaluate the style of every house sample in DPB settlements. Since the used style refers to vernacular architecture, then the determination of style can be separated into vernacular style, semi-vernacular style and nonvernacular style. This style determination evaluated by how much the house was changed refers to the three aspects. If some aspects are still dominated, and there are only a few changes without changing the original form, and then it can be said as a vernacular style. If 
there's a change in one of the aspects, but the rest aspects still have vernacular element and then it can be said as semi-vernacular style. If there's a dominating change on every aspect until the vernacular element left in small amount or already totally changed and then it can be said as non-vernacular style.

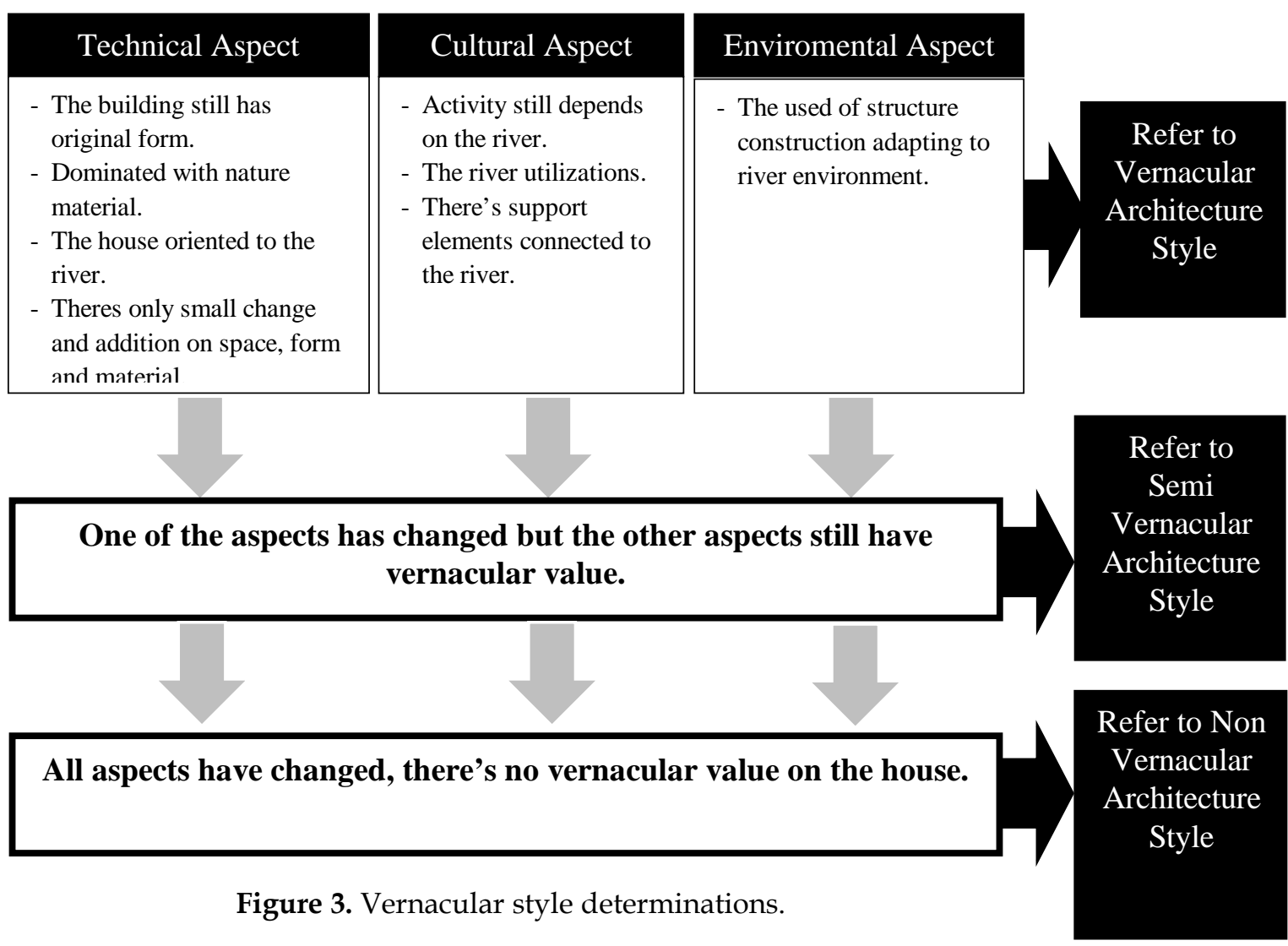

These vernacular style determinations are based to evaluate the houses that become the sample of DPB riverside settlements. From the population of the house, obtained 25 house samples match the determination criteria. Those riverside house samples then analyzed according to the style criteria determined before. Based on the analysis results, there is 2 types of style discovered from that 25 riverside house samples which are vernacular style and semivernacular style. From that 2 types of style, the house with vernacular style is more dominating, either on the riverside area or on the river surface. Bellows are the results of both style distribution corresponding with the position of the house.

Table 1: Style distributions in DPB Settlements.

\begin{tabular}{lcccc}
\hline \multirow{2}{*}{ Style } & \multicolumn{2}{c}{ Amount } & Total \\
\cline { 2 - 4 } & Riverside & Riverbank & $\begin{array}{c}\text { River Surface } \\
\text { /floating } \\
\text { house }\end{array}$ & Amount \\
\hline Vernacular Style Houses & 9 Houses & 1 House & 4 Houses & 14 Houses \\
Semi-vernacular Style Houses & 1 House & 11 Houses & - & 12 Houses \\
\hline & TOTAL & & 25 Houses \\
\hline
\end{tabular}




\section{Vernacular Style Houses}

The first style is Vernacular Architecture Style, the houses that have this style tends to maintain the original building form. They were dominated by the natural material like woods as the form of the house. The used of this woods material was caused by this material pretty easy to get in Banjarmasin City. Even though dominated by woods material, there's a few changes into the recent building material, such as the changes of roof cover or the wall material. This changes triggered by the decayed of old materials besides, the material changes like the roof covers into iron sheeting effects the material durability, because the natural type of roof covers like shingle or roof of rumbia leaves has short durability and easy to burnt, so the people mostly change their roof into iron sheeting materials.

The choice of these material replacements also based on economic considerations of its house residents, the more established they are the used materials also become more diverse and they can even change the whole house materials. Meanwhile, for the low-income residents, the material changes tend into cheaper materials or just by doing some patch with sober materials. They only change the material of the broken area. This material changes aspect will later influence the determination of building style value.

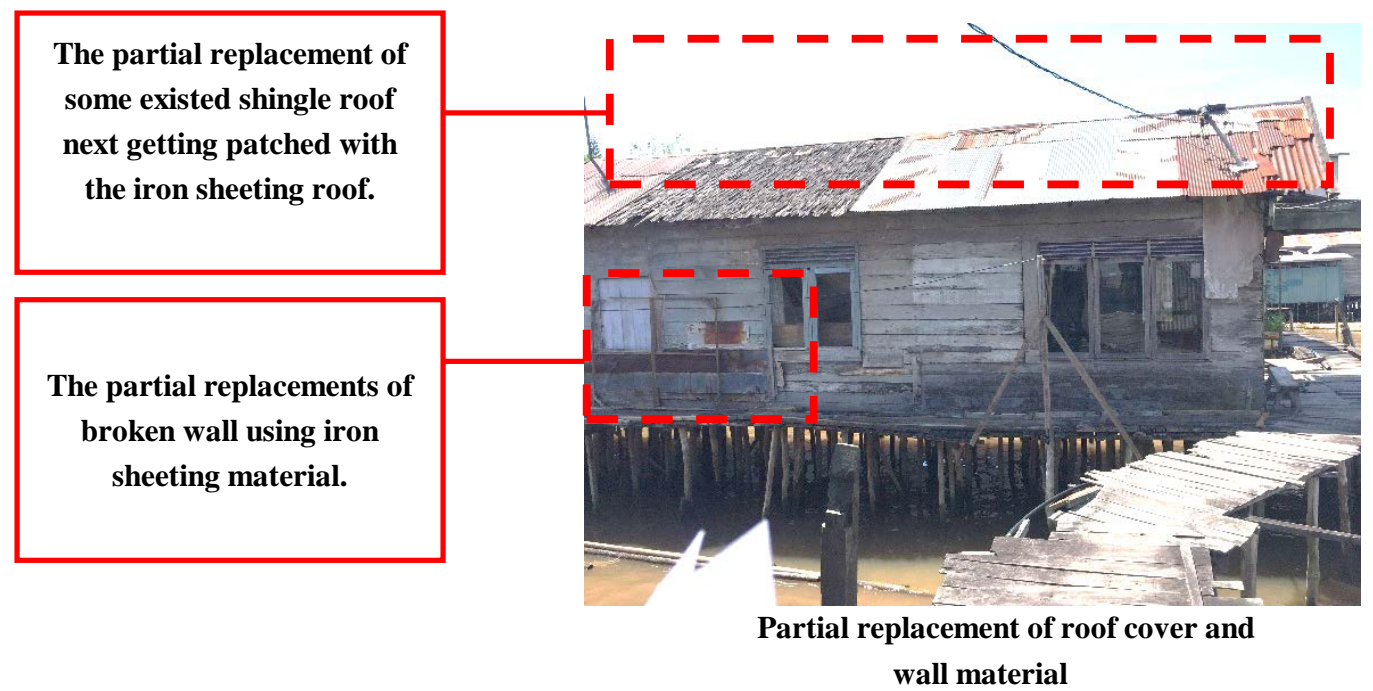

Figure 4. House material replacement.

The reside culture in DPB riverside settlements is generally still very strong. Seen from the culture aspect, the house with this style still really depends on the river, the residents' activity cannot be separated from the river environment which is their living space. Many of the residents of the house still using river area as their bathing, washing, and toilet space (MCK) by making use of the support elements like batang, titian, dermaga and jamban either on river area or on their house. These things are the results of their never vanished habit to do activities in the river area. The transportations type used in this riverside society are diverse, besides water transportation there's also other transportation like motorcycle, but since this settlements area stands on the middle of river and there's no access of passing bridge, so the main transportation they used is still the water transportations such as jukung (paddle boat), kelotok (motorized boat) or ferry. The stands out activity in these DPB riverside settlements are the trading they did on the river. In history, this river trading activity becomes the pioneer of the riverside settlements formed in Banjarmasin City. Besides on DPB Settlements, we 
rarely or even can't found this trading activity in any the other settlements. This is the reasons why the culture of these DPB riverside houses are still very strong.

The environmental aspect of the houses with this style determined by the used of environmentally friendly construction material. Since this DPB Settlements area is a delta surrounded by rivers, the house construction should be adapt to the environment. The adaptation way of these houses are using the stilt house and floating foundation structure. The stilt foundation system is used to not interrupt the river's flow, so the balance of nature and artificial environment can be made. These following are examples of vernacular style houses.
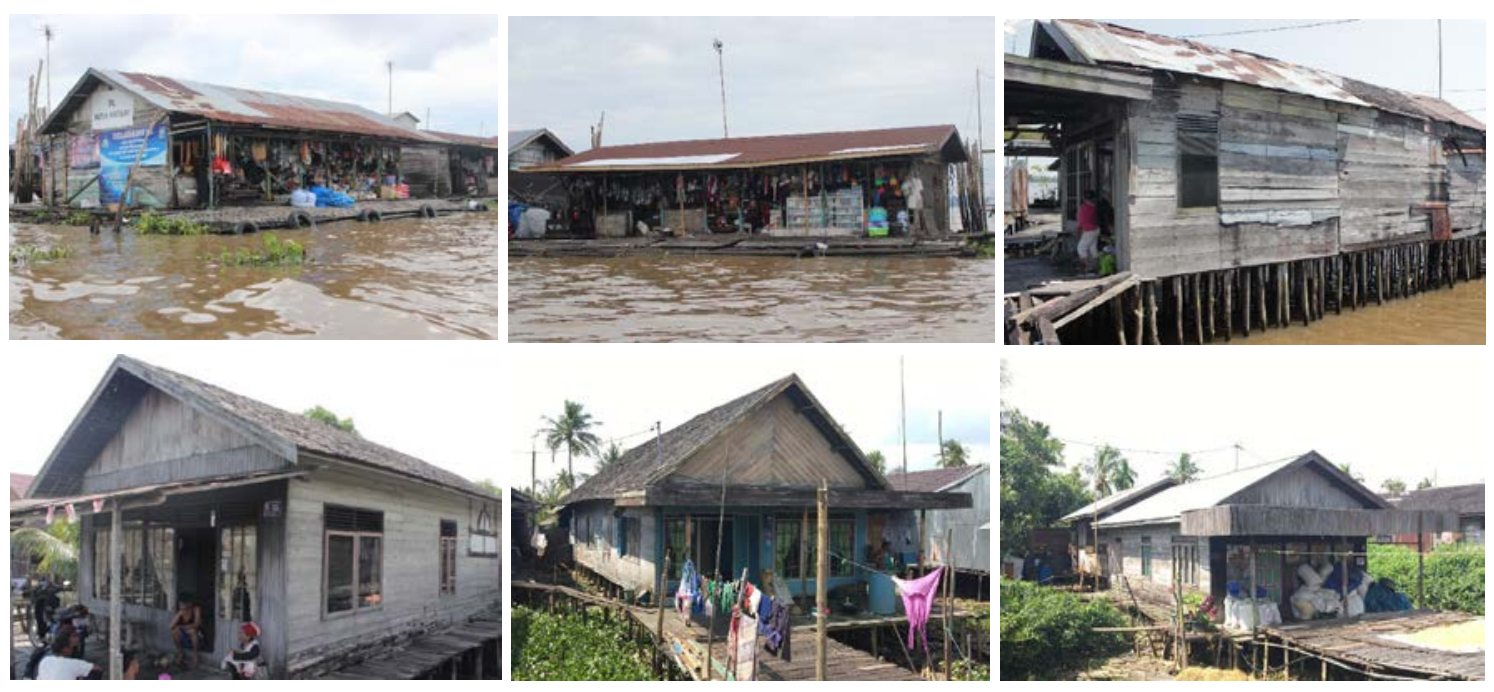

Figure 5: Vernacular style houses.

\section{Semi vernacular style houses}

The second style is semi vernacular architecture, the houses with this style are the houses that already had some changes on one of the aspects. The changed aspect of this type of house is a technical aspect, for the cultural and environmental aspects, are still similar to the first style, such as the people activity that is still depend on the river, the used of the support elements to connect the residents to the river also the constructions adaptation to the river environment.

The affecting aspect of this building style determination is the technical aspect that has some replacement inside it. Some house of this style had some changes on the foundation and the addition of the building's function. Almost all of the riverside houses are included in semi vernacular style, this was caused by the foundation durability considerations. The structure system replacements happen to the floating house on the river surface.

The floating house has high vernacularity value, caused by the adaptations to its nature environment that are rivers. By the development time, the floating material for the house in the form of wood logs getting difficult to be found, thus the residents choose to change the material into bamboo sticks that are easier to get. The used of these bamboo sticks still not changes the floating house foundations system. The used of bamboo sticks got a weakness, the durability is not that good so its need to get replacements periodically. This becomes a problem for the residents, so they start to change the floating foundations into stilt house foundations with ulin woods material. This technology was already applied to the existing riverside stilt houses, caused by the galam woods characteristic that has high durability against the water so the residents don't need to periodically change their foundations. This 


\section{Architectural Style of Riverside Settlements in Banjarmasin City}

Amar Rizqi Afdholy, Lisa Dwi Wulandari, Sri Utami

foundation changed indirectly influence the form and value towards the houses styles. Thus the riverside houses which were form as floating house and had more than 50 years ago can't be determined as a pure vernacular style, and more determined as semi vernacular style. This was caused by the dominant changes in the building form, even the building plan and foundation already changed but they still adaptable to the nature.

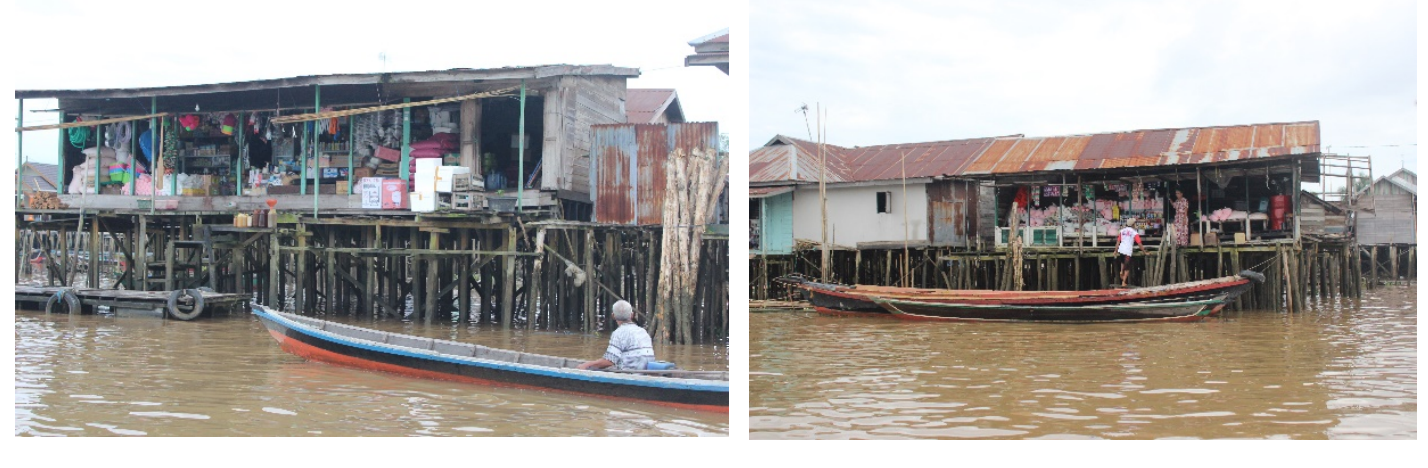

Figure 6. Floating house changes into stilt house.

Besides that, there is also function addition to this semi vernacular house, this addition was caused by the living needs in the house that was at first only used for trading function. There's also space additions inside the house beside the function additions. The space additions usually added to the back area of the house such as service areas like laundry and bathing/toilet space. This addition influenced by the riverside house residents culture changes. In the earlier times the people activity included bathing, washing, and toilet (MCK) were happened on the river with the used of batang or jamban, but as the times going and the clean water supply already reach this settlement, the people tend to do their MCK activity on their own house.

To changes this natural material, many residents refer to the recent material like iron sheeting or metal tiles as their roof covers. Besides easy to get, this new material also has pretty good durability. The material replacements considerations of these houses were because the durability factors if they choose regular woods they will always need to maintain it with periodical replacements by the end the costs of repairments get raised. Even in the opposite way, if they choose to use the high-quality woods, the repairment costs getting even more high, that it will affect the residents spend. Each day the woods price getting more expensive, it made the people should consider to another alternative of woods materials.

The changed of the foundation system, function and material replacements gave big differences to the house appearance, so the house would not seem like its original form. This become one of determinations term to evaluate the style of semi vernacular houses. Based on the space changes and addition on the technical aspect while the other aspects still have vernacular value thus the houses can still be determined as semi vernacular style. Bellow are a few houses determined as semi vernacular style.
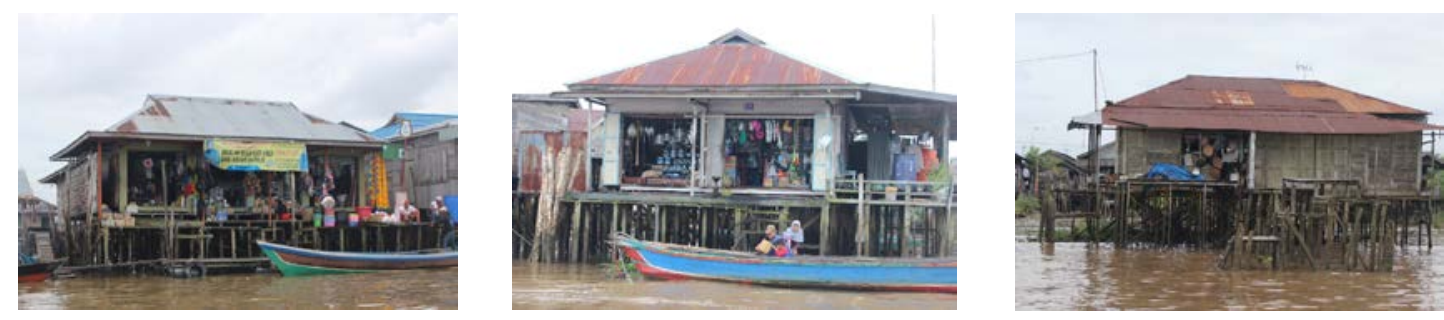

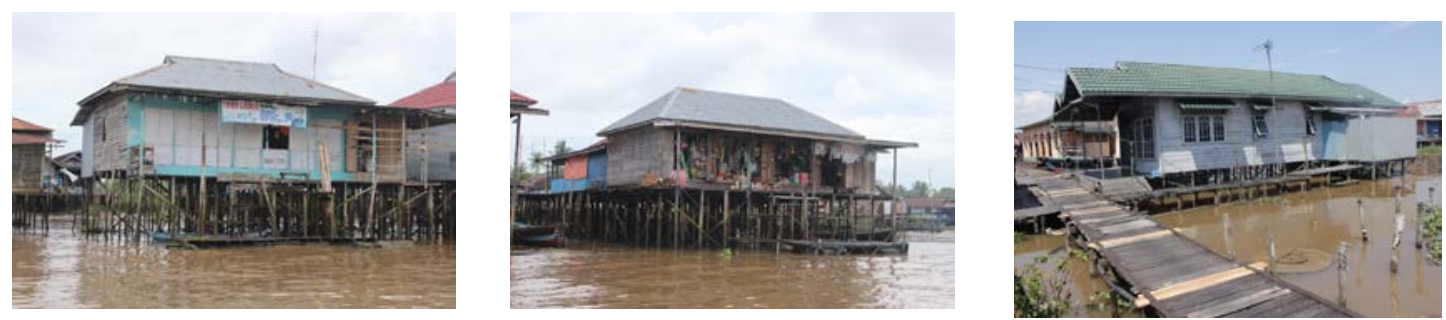

Figure 7:3.2 Semi vernacular style houses

\section{Conclusion}

There is two types of architecture style on the DPB riverside settlements, Banjarmasin City, which is the houses with vernacular style and semi vernacular style. The style determinations observed from building physical form, social activity of the residents and the adaptation of the house with their environment. Seen from its initial formations, the people lived in a settlements area growing in the vernacular houses. On its progress, that vernacular house certainly changes either indirectly or gradually way. The outside influences made houses as a place of activity need to follow it. Then that new culture appeared on people's life also affected the changes in progress in architecture and culture.

The more developed building technology made people become more critical in analyzing, especially related to the building's firm and material efficiency. The people don't need to cover themselves towards the new culture influenced comes from the outside. That will also affect the changes in settlements environment and its buildings. The knowledge of technology will give big influence on the characteristic of form, material and the houses structure, this technology usage affected by economic factors of the residents. These are the things become the factors of style diversity development in the riverside settlements of Banjarmasin City.

\section{Reference}

Abioso, W., S. (2011). Memahami “Urban” Vernacular Architecture. Majalah Ilmiah Unikom Bidang Teknik. 9 (2): 147-154.

Creswell, J. W. (2014). Research Design Pendekatan Kualitatif, Kuantitatif dan Campuran. Yogyakarta : Pustaka Pelajar.

Dahliani, Setijanti, P. \& Soemarno, I. (2016). Tantangan Keberadaan Rumah Lanting Sebagai Arsitektur Vernakular Tepi Air di Banjarmasin. Seminar Nasional - Semesta Arsitektur Nusantara 4. Malang: Jurusan Arsitektur Fakultas Teknik Universitas Brawijaya.

Iskandar, M. S. B. (2004). Tradisionalitas Dan Modernitas Tipologi Arsitektur Masjid. Dimensi Teknik Arsitektur. 32 (2): 110-118

Rahayu, S. N. N. (2017). Langgam Arsitektur dan Interior Museum Agung Bung Karno, Denpasar Bali. Jurnal Desain Interior. IV (1): 46-53.

Rapoport, A. (1969). House Form and Culture. Englewood Cliffs, N.J.: Prentice Hall.

Sudarwani, M. M. (2012). Simbolisasi Rumah Tinggal Etnis Cina Studi Kasus Kawasan Pecinan Semarang. Momentum. 8 (2): 19- 27. 


\section{Architectural Style of Riverside Settlements in Banjarmasin City}

Amar Rizqi Afdholy, Lisa Dwi Wulandari, Sri Utami

Mentayani, I. (2010). Tipomorfologi Rumah di Atas Air (Lanting) di Kalimantan Selatan dengan Pendekatan Case Study Research. Seminar Nasional Metodologi Riset dalam Arsitektur.

Mentayani, I. dan Prayitno, B. (2011). Arsitektur Tepian Sungai: Potret Life Style Masyarakat di Kota Banjarmasin. Seminar Nasional Dan Workshop Life Style And Architecture Yogyakarta: Universitas Atmajaya.

Mentayani, I. dan Ikaputra. (2012). “Menggali Makna Arsitektur Vernakular: Ranah, Unsur dan Aspek-Aspek Vernakularitas". Lanting Journal of Architecture. 1 (2): 68-82.

Mentayani, I. (2016). Identitas Keruangan Tepian Sungai Dan Perubahannya Pada Permukiman Vernakular Di Banjarmasin. Seminar Nasional - Semesta Arsitektur Nusantara 4, Malang: Jurusan Arsitektur Fakultas Teknik Universitas Brawijaya. 